\title{
Evidence of Instability in Previously-Mapped Landslides as Measured Using GPS, Optical, and SAR Data between 2007 and 2017: A Case Study in the Portuguese Bend Landslide Complex, California
}

\author{
El Hachemi Bouali $1,2, * \mathbb{C}$, Thomas Oommen ${ }^{1}\left(\mathbb{D}\right.$ and Rüdiger Escobar-Wolf ${ }^{1}$ \\ 1 Department of Geological and Mining and Engineering Sciences, Michigan Technological University, \\ 1400 Townsend Drive, Houghton, MI 49931, USA; toommen@mtu.edu (T.O.); rpescoba@mtu.edu (R.E.-W.) \\ 2 Environmental Science Program, Trinity College, 300 Summit Street, Hartford, CT 06106, USA \\ * Correspondence: elhachemi.bouali@trincoll.edu
}

Received: 8 March 2019; Accepted: 16 April 2019; Published: 18 April 2019

check for updates

\begin{abstract}
Velocity dictates the destructive potential of a landslide. A combination of synthetic aperture radar (SAR), optical, and GPS data were used to maximize spatial and temporal coverage to monitor continuously-moving portions of the Portuguese Bend landslide complex on the Palos Verdes Peninsula in Southern California. Forty SAR images from the COSMO-SkyMed satellite, acquired between 19 July 2012 and 27 September 2014, were processed using Persistent Scatterer Interferometry (PSI). Eight optical images from the WorldView-2 satellite, acquired between 20 February 2011 and 16 February 2016, were processed using the Co-registration of Optically Sensed Images and Correlation (COSI-Corr) technique. Displacement measurements were taken at GPS monuments between September 2007 and May 2017. Incremental and average deformations across the landslide complex were measured using all three techniques. Velocity measured within the landslide complex ranges from slow ( $>1.6 \mathrm{~m} /$ year) to extremely slow $(<16 \mathrm{~mm} /$ year). COSI-Corr and GPS provide detailed coverage of $\mathrm{m} /$ year-scale deformation while PSI can measure extremely slow deformation rates (mm/year-scale), which COSI-Corr and GPS cannot do reliably. This case study demonstrates the applicability of SAR, optical, and GPS data synthesis as a complimentary approach to repeat field monitoring and mapping to changes in landslide activity through time.
\end{abstract}

Keywords: Remote sensing; landslide; optical; SAR

\section{Introduction}

The destructive capabilities of a landslide depend on its velocity and proximity to assets deemed valuable to human livelihood [1]. Unfortunately, many landslides occur in areas that put human life and societal assets (e.g., homes, infrastructure, transportation networks) at risk [2,3]. It is important for communities to identify areas susceptible to landslides and perform necessary preventative measures, which may in some form include spatial identification (e.g., landslide inventory) and temporal monitoring (e.g., displacement measurements), to establish a community landslide mitigation plan $[4,5]$. Observational landslide identification and monitoring can take many forms [6-23]: repeat mapping expeditions with qualitative descriptions, quantitative field assessments and installation of in situ monitoring equipment (e.g., inclinometers or GPS monuments), and remote sensing surveys (terrestrial, aerial, or satellite-based). The authors utilize similar data-the California landslide inventory [24-27], annual displacement measurements at GPS monuments [28], and two satellite-based remote sensing techniques: Persistent Scatterer Interferometry (PSI) and Co-registration of Optically Sensed Images and Correlation (COSI-Corr) — to map and update the extent of recent landslide activity 
(2007-2017) within a landslide complex and create a landslide activity map based on the Cruden and Varnes [29] landslide velocity scale.

Combining multiple techniques allows for a more robust observational dataset over the area of interest. Multi-sensor approaches have been utilized in other recent geomorphological studies [30-33]. Typically, a remote sensing approach is combined with a ground-based geodetic or in situ technique: the former provides relative measurements and extensive spatial and/or temporal dimensions while the latter allows for absolute measurements and ground-truthing (of remote sensing data). Many previous landslide studies have proven the efficacy of pairing datasets from a ground-based source with a remote sensing-based source: GPS measurements have been combined with PSI [34-44] and with COSI-Corr [45-47]; in situ measurements (e.g., inclinometers) have been combined with PSI [48-53] and, to a lesser extent, with optical correlation methods, of which COSI-Corr is one [54-56]. In this case of landslide deformation monitoring and mapping, PSI, COSI-Corr, and GPS measurements are merged to maximize spatial and temporal coverage but also, as shown in Table 1, to reduce limitations of a single technique. For example, COSI-Corr and GPS can reliably measure ground deformation rates in the $\mathrm{cm} /$ year to $\mathrm{m} /$ year range, but neither have the accuracy to measure sub-cm/year velocity; PSI, on the other hand, can measure deformation at the $\mathrm{mm}$ /year-scale by increasing the signal-to-noise ratio through image stacking $[57,58]$, but suffers from phase decorrelation at greater displacement rates [59].

Table 1. Variables to consider prior to mapping and monitoring of landslides using Persistent Scatterer Interferometry (PSI), Co-registration of Optically Sensed Images and Correlation (COSI-Corr), and GPS.

\begin{tabular}{|c|c|c|c|}
\hline & PSI & COSI-Corr & GPS \\
\hline $\begin{array}{c}\text { Spatial Distribution of } \\
\text { Data Points }\end{array}$ & $\begin{array}{l}\text { Unknown until processing } \\
\text { complete }\end{array}$ & $\begin{array}{c}\text { Gridded across spatial extent } \\
\text { of input imagery }\end{array}$ & $\begin{array}{l}\text { Installed; must be placed } \\
\text { in areas where not } \\
\text { disturbed by external } \\
\text { factors }\end{array}$ \\
\hline $\begin{array}{c}\text { Temporal Distribution of } \\
\text { Data }\end{array}$ & $\begin{array}{c}\text { Spans acquisition period of } \\
\text { sensor }\end{array}$ & $\begin{array}{c}\text { Spans acquisition period of } \\
\text { sensor }\end{array}$ & $\begin{array}{l}\text { Spans acquisition period } \\
\text { post-installation }\end{array}$ \\
\hline $\begin{array}{l}\text { Range of Measurable } \\
\text { Deformation Rates }\end{array}$ & $\begin{array}{l}<2.5 \mathrm{~cm} / \text { year (threshold } \\
\text { changes based on data quality, } \\
\text { number of images, and radar } \\
\text { wavelength) }\end{array}$ & $\mathrm{cm} /$ year to m/year & $\mathrm{cm} /$ year to $\mathrm{m} /$ year \\
\hline $\begin{array}{l}\text { Direction(s) of } \\
\text { Measurements }\end{array}$ & $\begin{array}{l}\text { 1-dimensional, sensor } \\
\text { line-of-sight }\end{array}$ & $\begin{array}{l}\text { 2-dimensional, horizontal } \\
\text { (north-south and east-west) }\end{array}$ & $\begin{array}{l}\text { 3-dimensional, } \\
\text { horizontal and vertical }\end{array}$ \\
\hline Accuracy & $1 \mathrm{~mm} /$ year & 5-10 cm/year & $1-2 \mathrm{~cm} /$ year \\
\hline Sources of Noise & $\begin{array}{l}\text { Ionospheric effects, snow } \\
\text { cover, precipitation, changes in } \\
\text { dielectric properties of } \\
\text { materials, vegetation, } \\
\text { systematic noise }\end{array}$ & $\begin{array}{c}\text { Cloud cover, snow cover, } \\
\text { vegetation, drastic changes } \\
\text { in ground surface (e.g., } \\
\text { construction), systematic } \\
\text { noise }\end{array}$ & $\begin{array}{c}\text { Rapid ground } \\
\text { deformation (destruction } \\
\text { of monuments), external } \\
\text { factors (e.g., humans and } \\
\text { animals) }\end{array}$ \\
\hline $\begin{array}{l}\text { Measurements } \\
\text { Unavailable } \\
\text { (Decorrelation) or } \\
\text { Unreliable }\end{array}$ & $\begin{array}{l}\text { Dense vegetation, topographic } \\
\text { shadow zones, areas with } \\
\text { rapid ground deformation }\end{array}$ & $\begin{array}{c}\text { Areas beneath clouds, dense } \\
\text { vegetation, topographic } \\
\text { shadow zones }\end{array}$ & $\begin{array}{l}\text { If impacted by sources of } \\
\text { noise listed above }\end{array}$ \\
\hline Validation & $\begin{array}{l}\text { GPS and other } \\
\text { ground-truthing methods }\end{array}$ & $\begin{array}{l}\text { GPS and other } \\
\text { ground-truthing methods }\end{array}$ & $\begin{array}{l}\text { Other ground-truthing } \\
\text { methods (e.g., surveys) }\end{array}$ \\
\hline
\end{tabular}

The authors present this approach with a specific focus to update the California landslide inventory in an area with continuously-moving landslides and high population density. The Portuguese Bend landslide complex is well-known because of its seemingly endless deformation and destruction of local assets, mainly transportation infrastructure and residential buildings. The region's high population density makes mapping the full extent of these landslides quite difficult since natural geologic features are paved over and built upon. Thus, the novel approach presented in this paper assists on two fronts: (1) to quantify maximum landslide velocity with GPS and COSI-Corr in the high hazard regions 
of the landslide complex where deformation is observable, and (2) to quantify and map areas with extremely slow deformation with PSI (mm/year-scale) near the perimeter of the landslide complex where residential neighborhoods have expanded to and may be in danger of long-term deformation or creep.

\section{Study Area}

An active landslide complex is located on the south-central coast of the Palos Verdes Peninsula in California. Residential neighborhoods of Rancho Palos Verdes, Rolling Hills, and Rolling Hills Estates delineate the perimeter of previously mapped landslides. At least eight major landslides form this complex (Figure 1), including Ancient Portuguese Bend (AnPB), Active Portuguese Bend (AcPB), Valley View Graben (VVG), Parcel 4 (P4), Abalone Cove (AC), Klondike Canyon (KC), Beach Club (BC), and Flying Triangle (FT), as mapped by the California Geological Survey [24]. Landslide mapping was originally performed through analysis of aerial photographs and then validated through field reconnaissance and topographic map interpretations [25-27]. Landslides were classified based on specific characteristics using terminology from Varnes [60], Wieczorek [61], Keaton and DeGraff [62], and Cruden and Varnes [29]. Characteristics include landslide type, thickness, activity (as shown in Figure 1), movement direction, and confidence of interpretation [24]; see Table 2 for characteristics of notable landslides.

Table 2. Landslide characteristics.

\begin{tabular}{cccccc}
\hline Landslide & Type & $\begin{array}{c}\text { Thickness } \\
(\mathbf{f t}, \mathbf{m})\end{array}$ & Activity & $\begin{array}{c}\text { Movement } \\
\text { Direction (azimuth) }\end{array}$ & $\begin{array}{c}\text { Interpretation } \\
\text { Confidence Level }\end{array}$ \\
\hline AnPB & Rock Slide & $\begin{array}{c}>50, \\
>15.24\end{array}$ & $\begin{array}{c}\text { Dormant } \\
\text { Old/Relict }\end{array}$ & 180 & Definite \\
\hline AcPB & Rock Slide & $\begin{array}{c}>50, \\
>15.24\end{array}$ & Active/Historic & 180 & Definite \\
\hline VVG & Rock Slide & $\begin{array}{c}>50, \\
>15.24\end{array}$ & $\begin{array}{c}\text { Dormant } \\
\text { Old/Relict }\end{array}$ & 180 & Definite \\
\hline P4 & Rock Slide & $\begin{array}{c}10-50, \\
3.05-15.24\end{array}$ & $\begin{array}{c}\text { Dormant } \\
\text { Old/Relict }\end{array}$ & 180 & Definite \\
\hline AC & Rock Slide & $\begin{array}{c}>50, \\
>15.24\end{array}$ & Active/Historic & 220 & Definite \\
\hline KC & Rock Slide & $\begin{array}{c}>50, \\
>15.24\end{array}$ & Active/Historic & 220 & Definite \\
\hline BC & Rock Slide & $\begin{array}{c}>50, \\
>15.24\end{array}$ & Active/Historic & 220 & Definite \\
\hline FT & Rock Slide & $\begin{array}{c}>50, \\
>15.24\end{array}$ & Active/Historic & 230 & Definite \\
\hline
\end{tabular}

The landslide complex is sliding south-southwest down the Palos Verdes Hills, a northwestsoutheast trending ridge located north of Rolling Hills and Rolling Hills Estates. All major landslides are classified as rock slides [24] where the moving mass includes bedrock and younger alluvium, the main body generally stays intact, and movement can be described as either translational or rotational, although larger landslides exhibit complex movements (both translational and rotational). The basal surface of rupture on these deep-seated landslides ( $>15 \mathrm{~m}$ in thickness) typically occurs along bedding planes of the tuffaceous unit of the Altamira Shale, the oldest member of the middle to upper Miocene Monterey Formation, parts of which have been altered to bentonite and montmorillonite [63,64]. Relatively impermeable tuff beds rest between clay-altered, highly absorbent bedding planes that act as a conduit for groundwater (the basal surface of rupture) and studies have observed a direct correlation between precipitation and landslide activity [24,65-67]. Landslide activity (Figure 1 and Table 2) was defined by the California Geological Survey using aerial photographs from 1952-1959 and 1994, and field work in the 1990s [24]; it is based on the terminology proposed by Keaton and 
DeGraff [62]. Dormant slides are those that have not moved for at least 100 years-old/relict slides have not moved in the last 10,000 years. They show evidence of erosion and are covered with vegetation. Active/Historic slides are those that have occurred recently (since the 1950s) or "within historic time," defined as occurring within the last 100 years.

The landslide complex was dormant prior to reactivation in 1956 and possibly caused by two anthropogenic factors that may have increased groundwater pore pressure, although Kayen et al. [67] acknowledge a lack of hydrologic data to support this hypothesis. First, Rancho Palos Verdes approved the construction of Palos Verdes Drive South, a road running parallel to the coastline, which cuts through the slope toe. Material and fill used for construction were piled nearby, potentially causing rapid loading. Second, irrigation practices from nearby neighborhoods may have contributed to elevated groundwater levels [68]. The 1956 reactivation occurred within portions of AcPB. In February 1974, southern AC also began moving [69]. Heavy rainfall in early 1978 accelerated deformation within the entirety of both AcPB and AC landslides [66]. A 1979 field investigation by Proffer [69] concluded that short-term instability of AC was caused by increased groundwater levels and long-term instability by wave erosion of the toe. Eight dewatering wells were installed within the AC landslide boundary in 1980, significantly mitigating landslide hazard [69]. In 1984, dewatering wells were also installed in the AcPB landslide $[67,68]$. Other active landslides in the area were moving by the early-to-mid-1980s [68,69] and have been continuously moving since, exhibiting accelerated deformation rates $(>2.6 \mathrm{~m} /$ year $)$ during rainy months and decelerated deformation rates $(<1 \mathrm{~m} /$ year $)$ during dry months $[65,67]$. In recent years, coastline roads (including Palos Verdes Drive South) had to be repaired, replaced, or rerouted [70] and mitigation of the landslide complex is a continued topic of debate [71].

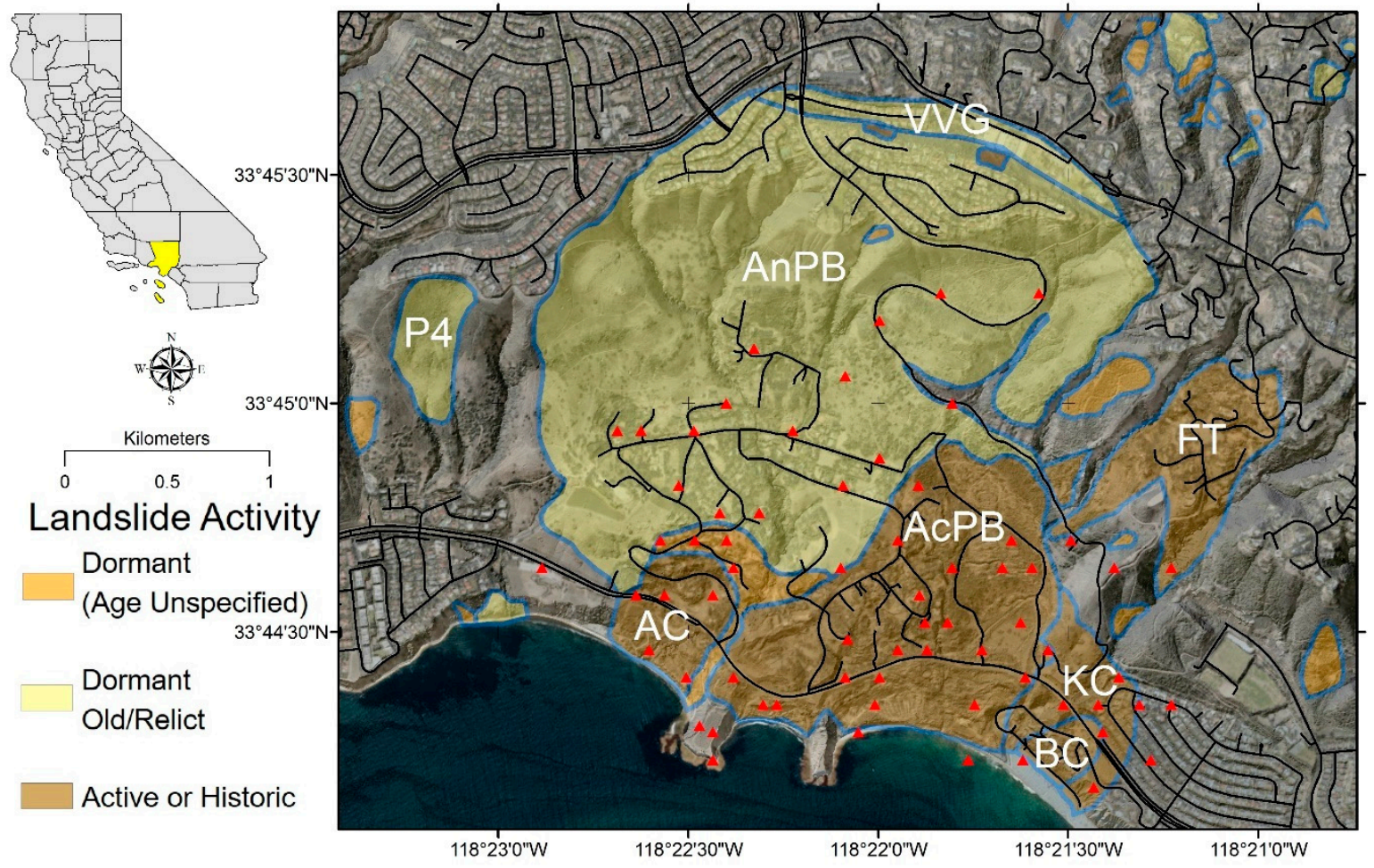

Figure 1. Study area. Inset shows location of Los Angeles County (highlighted in yellow) within the state of California. Major landslides, colored based on landslide activity [24], are Ancient Portuguese Bend (AnPB), Active Portuguese Bend (AcPB), Valley View Graben (VVG), Parcel 4 (P4), Abalone Cove (AC), Klondike Canyon (KC), Beach Club (BC), and Flying Triangle (FT). Boundaries between each landslide are shown in blue. GPS monuments are displayed as red triangles. Roads are shown as black lines. Background hillshade produced by [72]. 


\section{Data and Methodology}

Three deformation monitoring techniques-GPS, COSI-Corr, and PSI-have been used to study the continuously-moving Portuguese Bend Landslide complex. These three techniques were chosen to complement each other, as described in Table 1. Complete descriptions of the geodetic (GPS) and remote sensing (COSI-Corr and PSI) data and the methodology used in this case study are provided in the subsections below. GPS data are used to ground-truth COSI-Corr and PSI displacement and velocity measurements.

\subsection{GPS}

GPS surveys within the Portuguese Bend Landslide complex were conducted by Michael McGee, of McGee Surveying Consulting, on behalf of the City of Rancho Palos Verdes. Sixty-six GPS monuments were placed in a $\sim 4 \mathrm{~km}^{2}$ area, with a focus on the more active $\mathrm{AcPB}, \mathrm{KC}, \mathrm{BC}$, and $\mathrm{AC}$ landslides, and partial coverage of AnPB and FT (Figure 1). This GPS survey was a continuation of an original survey which began in 1994 and included 149 monuments, but 89 monuments were lost or destroyed, some due to rapid landslide deformation mainly in AcPB [28]. McGee resumed annual monitoring of all GPS monuments (60 found from 1994 survey and six new) in September 2007 and continued through May 2017 (most recent dataset available). A subset of monuments (about 30) were chosen for semiannual monitoring beginning February 2012 and triannual monitoring beginning April 2014. All the information for this project, entitled 'Portuguese Bend Landslide Monitoring Surveys,' including project history, datums and reference system, data collection, equipment and processing, Global Navigation Satellite System (GNSS) network diagram and description, accuracy, and quality control/quality assurance may be found in a series of reports from the City of Rancho Palos Verdes [28]. These GPS measurements are accurate to $1 \mathrm{~cm}$ (in relatively stable areas) and $2 \mathrm{~cm}$ (in active areas) between annual readings [28].

\subsection{COSI-Corr}

Co-registration of Optically Sensed Images and Correlation (COSI-Corr) is an optical remote sensing technique and ENVI software module [73,74]. It was originally created to measure ground deformation from seismic activity with satellite or aerial optical image pairs-a pre-event image and post-event image [75]. COSI-Corr measures two-dimensional (horizontal) ground deformation between image pairs, with displacement vectors in the north/south and east/west directions. Although designed to measure earthquake-induced deformation, COSI-Corr has been successfully used to measure geomorphological and surficial processes [47,76-79].

Eight WorldView-2 high resolution $(50 \mathrm{~cm}$ ) panchromatic optical images were acquired between 20 February 2011 and 16 February 2016. Images were obtained at an incidence angle of $20^{\circ}$ in the 450-800 nm spectral range. Operated by DigitalGlobe, images were processed to the map scale 1:12,000 orthorectified level. Full-size WorldView- 2 images were cut to only include the spatial extent covered by the landslides identified in Figure 1 and Table 2 and distributed by ESA through a written proposal (ID 36617). The final output to COSI-Corr processing is a deformation map which includes two-dimensional horizontal displacement measurements (north/south and east/west components) and a signal-to-noise ratio (SNR) at each pixel. SNR values range from 0 (all noise) to 1 (no noise). This procedure was then repeated for all image pairs and yielded seven deformation maps, which were then summed to produce a total deformation map.

Although the accuracy of COSI-Corr displacement measurements depends on many factors, Leprince [80] shares an accuracy estimation based on image pixel size. Leprince [80] states, "The typical uncertainty on the displacement measurement is on the order of $1 / 10$ of the nominal image pixel size." Thus, the accuracy of displacement measurements in a deformation map created with a pair of WorldView-2 images should be approximately $5 \mathrm{~cm}$. The accuracy of the total deformation map, 
the summation of seven deformation maps from seven pairs of WorldView-2 images, should be approximately $35 \mathrm{~cm}$.

\subsection{PSI}

Persistent Scatterer Interferometry (PSI) is a remote sensing technique that measures geophysical and geometric changes of ground targets using synthetic aperture radar (SAR) image stacks [57,58]. Coherent points, known as persistent scatterers (PS), are identified in every image to produce a point cloud, and each PS within the point cloud includes enough data to create a displacement-time series. PSI has been widely used for long-term monitoring of dynamic processes, with many recent studies focusing on landslides [36,52,81-91].

Forty descending COSMO-SkyMed SAR images (level 1A: single-look complex slant products) were initially acquired between 19 July 2012 and 27 September 2014 by the Italian Space Agency (ASI). Images were acquired at a frequency of $9.6 \mathrm{GHz}$-corresponding wavelength of $3.1 \mathrm{~cm}(X$-band $)$-in STRIPMAP HIMAGE mode ( $26^{\circ}$ incidence angle) with a spatial resolution of $3 \mathrm{~m}$. Images were provided by the European Space Agency (ESA) through a written proposal (ID 31684).

Level 1A products arrive as focused data in slant range, complex form with no Doppler projection, and include the following pre-processing steps (performed by ASI from Level 0 RAW products): gain receiver compensation, internal calibration, data focusing, statistics estimation of the output data, and data formatting into output [92]. COSMO-SkyMed SAR images were processed with the ENVI + SARscape PSI software package [93]. The result is a PS point cloud. Every PS in the point cloud contains the following information: displacement $(\mathrm{mm})$ at each acquisition; average velocity ( $\mathrm{mm} /$ year); coherence; location within three-dimensional, geocoded coordinate system $(\mathrm{x}, \mathrm{y}, \mathrm{z})$; line-of-sight incidence angle and azimuth direction of SAR signal; original location within slant range coordinate system (azimuth, range); precision estimates of height $(\mathrm{m})$ and velocity $(\mathrm{mm} / \mathrm{year})$.

\section{Results and Discussion}

\subsection{GPS and COSI-Corr: Measuring $\mathrm{cm}$ - to $\mathrm{m}$-scale Deformation}

Maps illustrating the spatial extent of incremental displacement as measured by 66 GPS stations [28] between 24 September 2007 and 3 May 2017 are provided in Figure 2. A maximum displacement $>20 \mathrm{~m}$ (average velocity $>2 \mathrm{~m} /$ year) was measured at the toe of AcPB. The most active region of the landslide complex is within the AcPB landslide block, which experienced incremental displacements $>1.5 \mathrm{~m}$ between annual surveys (orange and red arrows in Figure 2). Other regions of the landslide complex that experienced displacements between $1 \mathrm{~m}$ and $1.5 \mathrm{~m}$ (light green and yellow arrows in Figure 2) include AC (Figure 2A,C,D,I), FT (Figure 2A-E), and AnPB (Figure 2A,D) although the latter is mapped as dormant old/relict (Figure 1).

Average horizontal downslope velocity maps, as measured between eight chronological WorldView-2 images between 20 February 2011 and 16 February 2016 using COSI-Corr, are provided in Figure 3. The chronological maps show average horizontal velocity values ranging from $0.5 \mathrm{~m} /$ year to $6.2 \mathrm{~m} /$ year. Areas with an average horizontal velocity $<0.5 \mathrm{~m} /$ year are transparent and are either stable or fall within the noise range. These average horizontal velocity results are draped over a $3 \mathrm{~m}$ digital elevation model [72] to illustrate that deformation occurs in the downslope direction. 

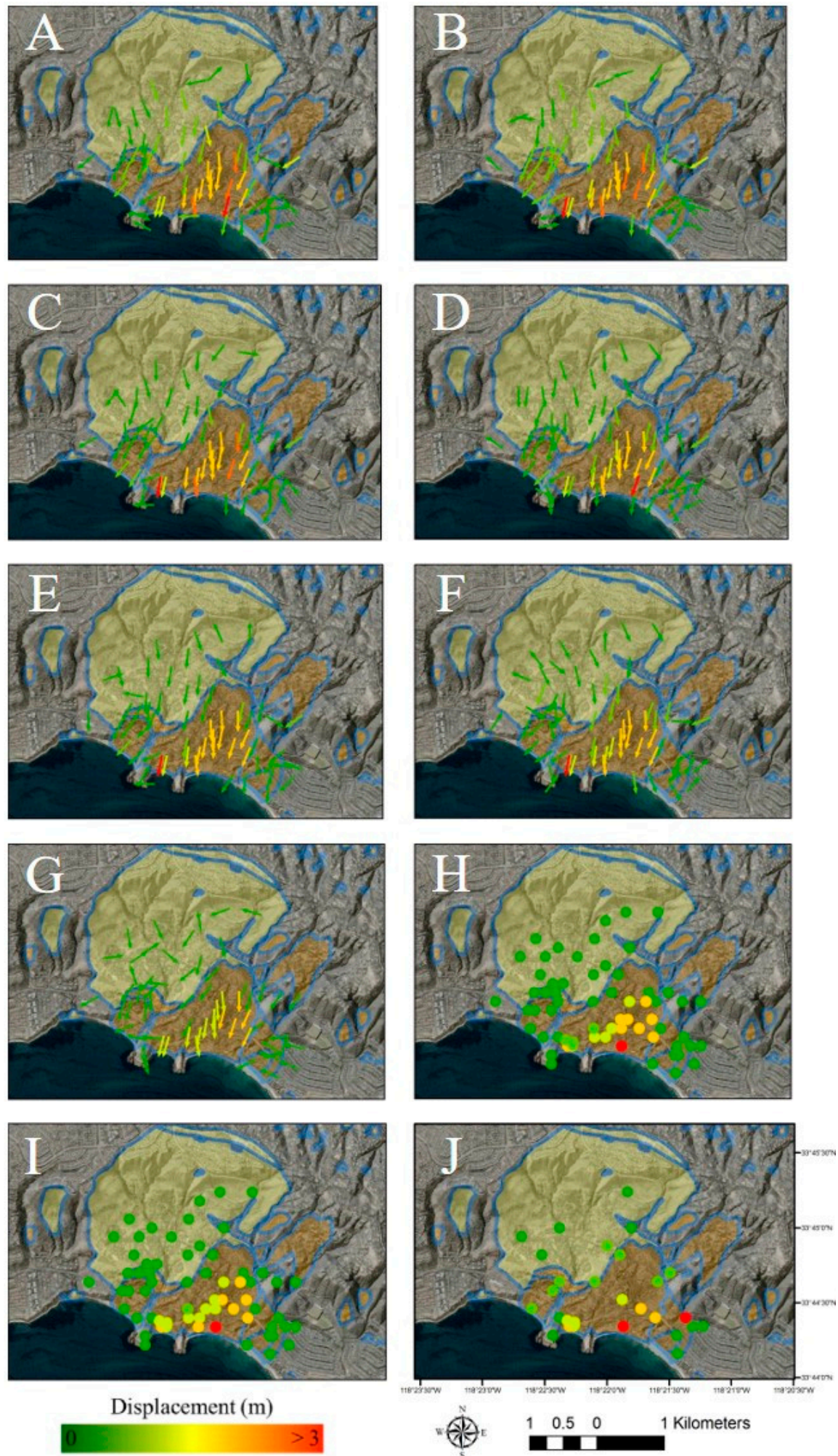

Figure 2. Incremental displacement (m) measured through annual GPS surveys from [28]: (A) 24 September 2007-10 December 2008; (B) 10 December 2008-18 November 2009; (C) 18 November 2009-25 October 2010; (D) 25 October 2010-3 October 2011; (E) 3 October 2011-14 September 2012; (F) 14 September 2012-4 October 2013; (G) 4 October 2013-19 September 2014; (H) 19 September 2014-8 October 2015; (I) 8 October 2015-5 October 2016; (J) 5 October 2016-3 May 2017. Displacement magnitude shown using color scale (green to red). Displacement direction shown using arrows (displacement direction unavailable for $\mathbf{H}, \mathbf{I}$, and $\mathbf{J}$ ). 

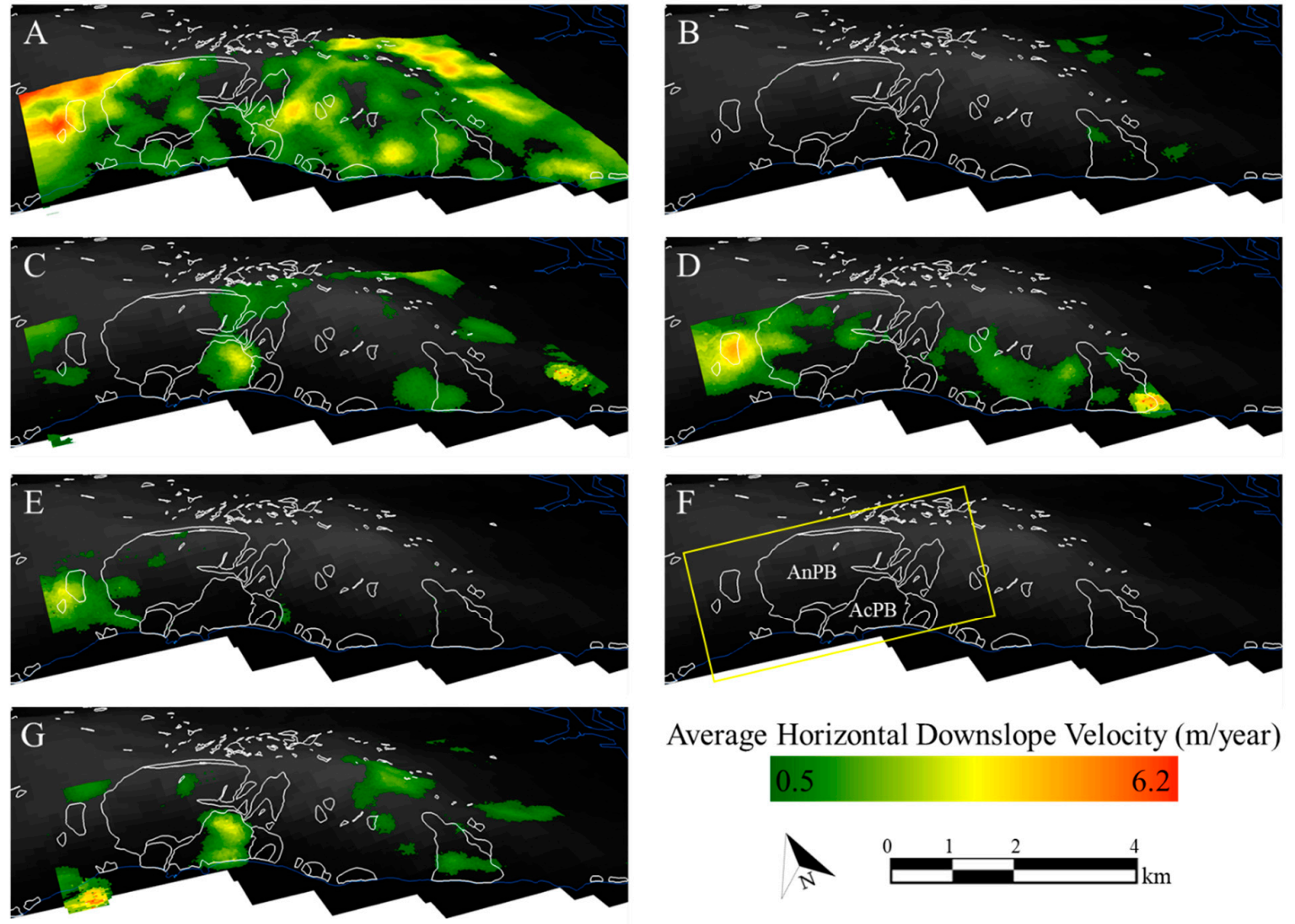

Average Horizontal Downslope Velocity ( $\mathrm{m} /$ year)

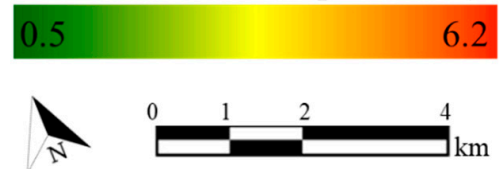

Figure 3. Incremental average horizontal downslope velocity (m/year) between chronological Worldview-2 image pairs. (A) 20 February 2011-29 May 2011; (B) 29 May 2011-17 February 2012; (C) 17 February 2012-9 November 2012; (D) 9 November 2012-15 September 2013; (E) 15 September 2013-29 March 2014; (F) 29 March 2014-17 September 2015; (G) 17 September 2015-16 February 2016. AnPB and $\mathrm{AcPB}$ are referenced in $(\mathrm{F})$ and the yellow rectangle delineates the approximate extent of the reference map provided in Figure 1.

Widespread deformation occurred throughout the Portuguese Bend landslide complex between 20 February 2011 and 29 May 2011 (Figure 3A); this timeframe is also encapsulated in GPS displacement measurements between 25 October 2010 and 3 October 2011 (Figure 2D). These widespread, relatively high rates of deformation in early 2011 correlate with a wet rainy season (December 2010 through March 2011). As shown in Figure 4, precipitation during this period was well above average in neighboring Los Angeles, California, with a total of 15.15 in of rain.

GPS, COSI-Corr, and precipitation data can be combined to create a unique, descriptive timeline of annual deformation in and around the Portuguese Bend landslide complex (as shown in Table 3).

GPS and COSI-Corr measurements can also be directly compared when analyzing temporal changes at a single location in the landslide complex. A velocity time series from the AcPB toe is provided in Figure 5. AcPB toe maintains a deformation rate between 0.8 and $1.0 \mathrm{~m} /$ year from late 2007 through early 2009. Deformation then accelerates to a peak velocity $>1.6 \mathrm{~m} /$ year in June 2010 . The toe then experiences a prolonged deceleration to a minimum velocity of $\sim 0.2 \mathrm{~m} /$ year in July 2014 . GPS and COSI-Corr data show the deceleration trend, although the latter shows a semi-cyclical fluctuation with a period of $\sim 18$ months. The final GPS and COSI-Corr average velocity points indicate the beginning of another period of acceleration beginning in December 2015. 
Table 3. Descriptive history of the Portuguese Bend landslide complex (2007-2017).

\begin{tabular}{|c|c|c|c|c|}
\hline Year(s) & $\begin{array}{l}\text { Measured } \\
\text { Deformation }\end{array}$ & Data Source & $\begin{array}{l}\text { Location of Deformation within Landslide } \\
\text { Complex }\end{array}$ & $\begin{array}{l}\text { Complementary } \\
\text { Figure(s) }\end{array}$ \\
\hline \multirow{3}{*}{ 2007-2008 } & $>1.5 \mathrm{~m}$ & GPS & Western and central regions of $\mathrm{AcPB}$ and FT & $2 \mathrm{~A}$ \\
\hline & $1 \mathrm{~m}-1.5 \mathrm{~m}$ & GPS & $\begin{array}{c}\text { Southeast region of } \mathrm{AnPB} \text { and north/northwest } \\
\text { regions of } \mathrm{AcPB}\end{array}$ & $2 \mathrm{~A}$ \\
\hline & $\begin{array}{l}\text { Relatively } \\
\text { Stable }\end{array}$ & GPS & $\mathrm{KC}$ and $\mathrm{BC}$ & $2 \mathrm{~A}$ \\
\hline \multirow{3}{*}{2009} & $1 \mathrm{~m}-1.5 \mathrm{~m}$ & GPS & $\begin{array}{l}\text { AcPB deformation decreases slightly (compared to } \\
\text { 2007-2008) }\end{array}$ & $2 \mathrm{~B}$ \\
\hline & $\sim 1 \mathrm{~m}$ & GPS & Eastern toe of FT & $2 \mathrm{~B}$ \\
\hline & $\begin{array}{l}\text { Relatively } \\
\text { Stable }\end{array}$ & GPS & $\begin{array}{l}\text { AnPB and AC (more stable than 2007-2008); KC } \\
\text { and BC }\end{array}$ & $2 \mathrm{~B}$ \\
\hline \multirow{3}{*}{2010} & $>1.5 \mathrm{~m}$ & GPS & $\begin{array}{l}\text { Central region of AcPB remains most active with an } \\
\text { increase in deformation since } 2009\end{array}$ & $2 \mathrm{C}$ \\
\hline & $\sim 1 \mathrm{~m}$ & GPS & Eastern toe of FT & $2 \mathrm{C}$ \\
\hline & $\begin{array}{l}\text { Relatively } \\
\text { Stable }\end{array}$ & GPS & $\mathrm{AnPB}, \mathrm{AC}, \mathrm{KC}$, and $\mathrm{BC}$ & $2 \mathrm{C}$ \\
\hline \multirow{3}{*}{2011} & $>1 \mathrm{~m}$ & GPS & Western and central AcPB, AC, and FT & $2 \mathrm{D}$ \\
\hline & $>1 \mathrm{~m}$ & COSI-Corr & $\begin{array}{l}\text { Widespread instability, } \\
\text { including areas not mapped as } \\
\text { landslides }\end{array}$ & $3 \mathrm{~A}$ \\
\hline & $\begin{array}{l}\text { Relatively } \\
\text { Stable }\end{array}$ & COSI-Corr & $\begin{array}{l}\text { Little significant deformation } \\
\text { outside landslide complex; none } \\
\text { within complex }\end{array}$ & 3B \\
\hline \multirow{3}{*}{2012} & $>1 \mathrm{~m}$ & $\begin{array}{c}\text { GPS, } \\
\text { COSI-Corr }\end{array}$ & Activity throughout AcPB & $2 \mathrm{E}, 3 \mathrm{C}$ \\
\hline & $\sim 1 \mathrm{~m}$ & GPS & Eastern toe of FT & $2 \mathrm{E}$ \\
\hline & $\begin{array}{l}\text { Relatively } \\
\text { Stable }\end{array}$ & $\begin{array}{l}\text { GPS, } \\
\text { COSI-Corr }\end{array}$ & $\mathrm{AnPB}, \mathrm{AC}, \mathrm{KC}$, and $\mathrm{BC}$ & $2 \mathrm{E}, 3 \mathrm{C}$ \\
\hline \multirow[t]{3}{*}{2013} & $3-4 \mathrm{~m}$ & COSI-Corr & $\begin{array}{c}\text { P4 is most active landslide, with displacement } \\
\text { peaking at } \sim 4 \text { m (September) before decreasing to } \\
\sim 3 \mathrm{~m}\end{array}$ & $3 \mathrm{D}, 3 \mathrm{E}$ \\
\hline & $>1.5 \mathrm{~m}$ & $\begin{array}{l}\text { GPS, } \\
\text { COSI-Corr }\end{array}$ & $\begin{array}{c}\text { AcPB remains active, mostly vertical displacement } \\
\text { since COSI-Corr does not capture any deformation } \\
\text { during this time }\end{array}$ & $2 \mathrm{~F}, 3 \mathrm{D}, 3 \mathrm{E}$ \\
\hline & $\begin{array}{l}\text { Relatively } \\
\text { Stable }\end{array}$ & $\begin{array}{l}\text { GPS, } \\
\text { COSI-Corr }\end{array}$ & $\mathrm{AnPB}, \mathrm{AC}, \mathrm{KC}$, and $\mathrm{BC}$ & $2 \mathrm{~F}, 3 \mathrm{D}, 3 \mathrm{E}$ \\
\hline \multirow[t]{2}{*}{ 2014-2015 } & $0.5 \mathrm{~m}-3 \mathrm{~m}$ & $\begin{array}{l}\text { GPS, } \\
\text { COSI-Corr }\end{array}$ & $\begin{array}{l}\text { AcPB remains active, mostly vertical displacement } \\
\text { until September } 2015 \text { when COSI-Corr measures } \\
\text { horizontal displacement ranging from } 0.5 \mathrm{~m} \\
\text { (landslide body) to } 3 \mathrm{~m} \text { (landslide head); }\end{array}$ & $2 \mathrm{G}, 2 \mathrm{H}, 3 \mathrm{G}$ \\
\hline & $\begin{array}{l}\text { Relatively } \\
\text { Stable to } \sim 0.5 \mathrm{~m}\end{array}$ & $\begin{array}{l}\text { GPS, } \\
\text { COSI-Corr }\end{array}$ & $\begin{array}{l}\text { All landslides adjacent to AcPB stable until } \\
\text { September } 2015 \text { when COSI-Corr measures } \sim 0.5 \mathrm{~m} \\
\text { displacement in AnPB }\end{array}$ & $2 \mathrm{G}, 2 \mathrm{H}, 3 \mathrm{G}$ \\
\hline \multirow[t]{2}{*}{2016} & $>3 \mathrm{~m}$ & GPS & $\begin{array}{l}\text { GPS stations within AcPB measure displacement }> \\
\qquad 3 \mathrm{~m} \text { at two locations }\end{array}$ & 2I \\
\hline & $\begin{array}{l}\text { Relatively } \\
\text { Stable }\end{array}$ & GPS & $\mathrm{AnPB}, \mathrm{AC}, \mathrm{KC}$, and $\mathrm{BC}$ & $2 \mathrm{I}$ \\
\hline \multirow{3}{*}{2017} & $>3 \mathrm{~m}$ & GPS & $\begin{array}{l}\text { GPS stations within AcPB measure displacement }> \\
\qquad 3 \mathrm{~m} \text { at two locations }\end{array}$ & $2 \mathrm{~J}$ \\
\hline & $\sim 1 \mathrm{~m}$ & GPS & Toe of AC & $2 \mathrm{~J}$ \\
\hline & $\begin{array}{l}\text { Relatively } \\
\text { Stable }\end{array}$ & GPS & $\mathrm{AnPB}$ and FT & $2 \mathrm{~J}$ \\
\hline
\end{tabular}




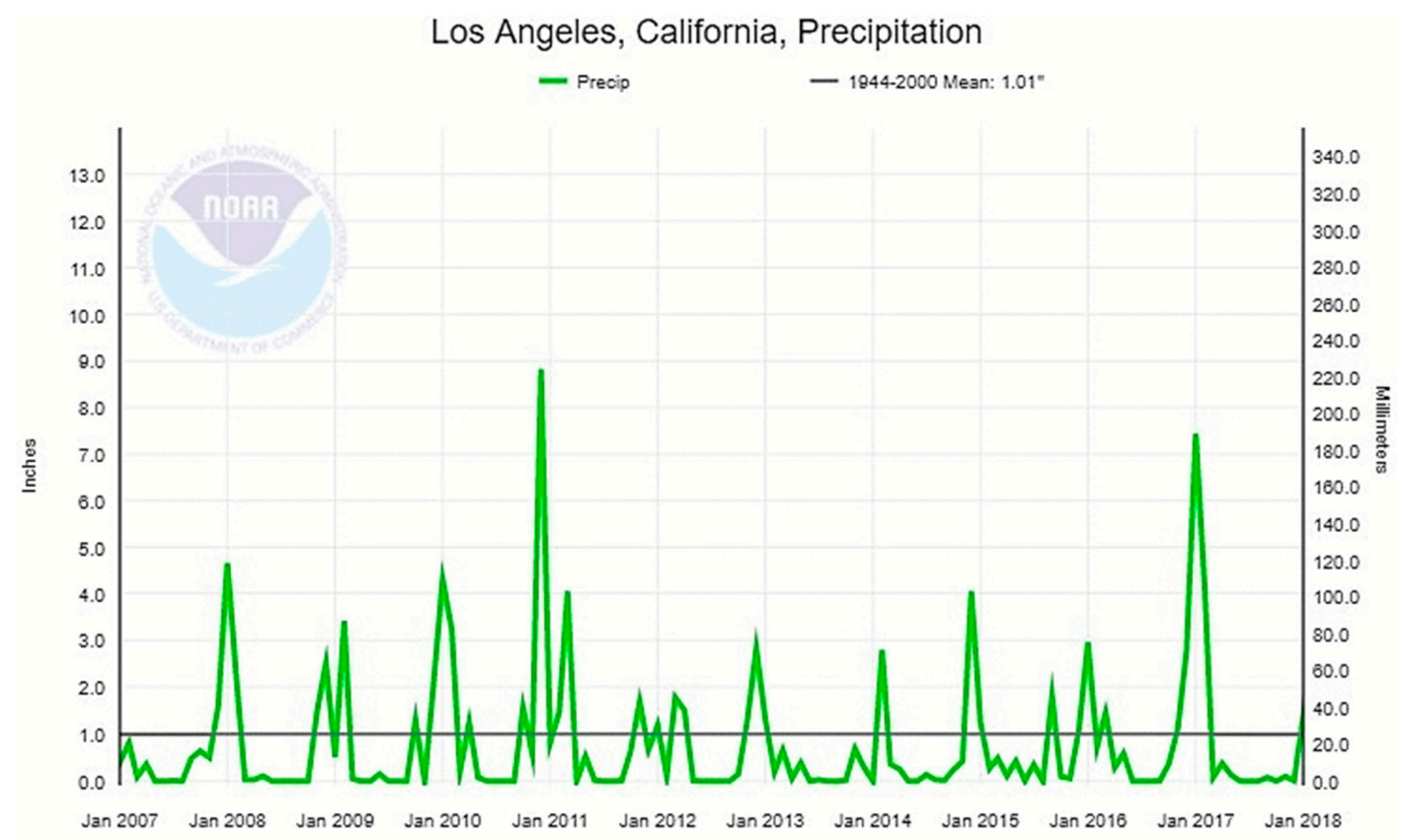

Figure 4. Precipitation time series for Los Angeles, California between January 2007 and January 2018 [95].

Temporal results across the landslide complex (when plotted like Figure 5) show deformation patterns identical to those expected from shallow-dipping translational landslides [94]; recall that landslides in this complex slip along bedding planes dipping at $5^{\circ}$ south-southwest toward the ocean. Therefore, most of the deformation will be measured in the horizontal components rather than the vertical component. At GPS station UB-2, GPS and COSI-Corr measurements show a similar average velocity time series trend (Figure 5). Remember, COSI-Corr measures deformation in the two horizontal planes and GPS measures deformation in three dimensions. Thus, if COSI-Corr measurements equal GPS measurements, as shown in Figure 5, then deformation primarily occurs nearer the two horizontal planes (north-south, east-west) and there is little or no vertical deformation in the region. These measurements match previous observations [24-27].

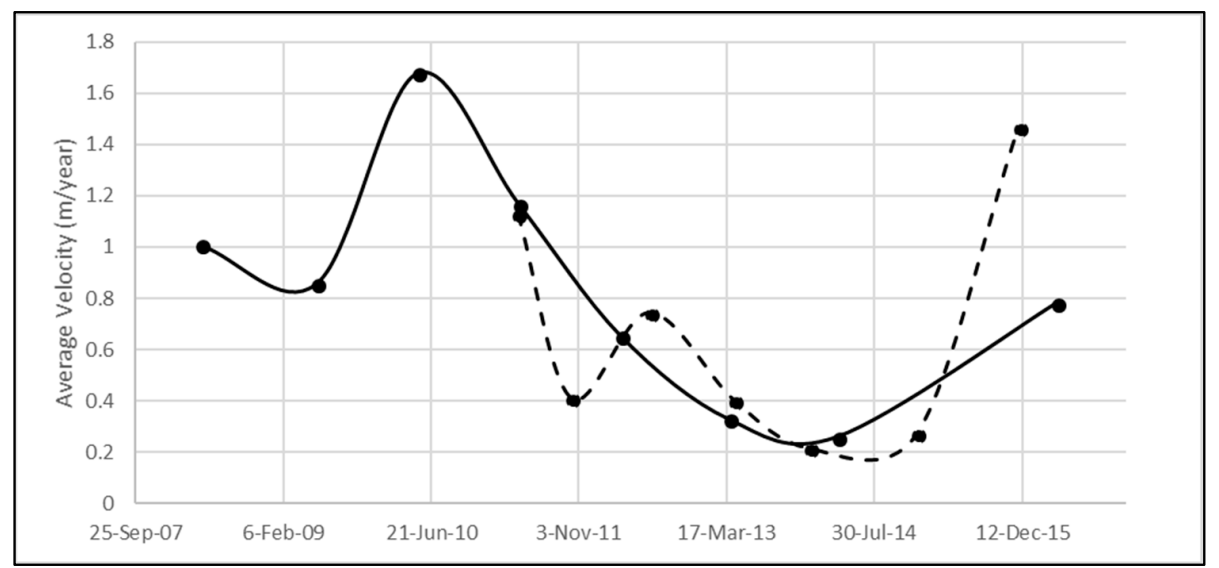

Figure 5. Average velocity time series with GPS (solid curve) and COSI-Corr (dashed curve) at GPS station UB-2 located at the toe of AcPB (the most active region of the Portuguese Bend landslide complex).

A comparison of total displacement measured by GPS and COSI-Corr, as shown in Figure 6, can be used as an accuracy assessment tool. In terms of accuracy, it should be expected that COSI-Corr measurements are less than or equal to GPS measurements at the same location (as discussed in the 
previous paragraph). As shown in Figure 6, there are five instances (out of 55 total) where COSI-Corr measurements exceed GPS measurements by at least $0.25 \mathrm{~m}$ (i.e., the five plot points and respective error bars lie below the red 1:1 line in Figure 6). Thus, COSI-Corr measurements at these five GPS stations may be inaccurate due to additional sources of noise that are not present at the other GPS stations.

Table 4. GPS displacement and COSI-Corr displacement comparison between 2012 and 2016 at 55 GPS stations (information from Figure 6).

\begin{tabular}{ccccc}
\hline Line of Best Fit Slope & Line of Best Fit Intercept & $\mathbf{R}^{2}$ Value & GPS Error Bars & COSI-Corr Error Bars \\
\hline 0.77 & 0.0133 & 0.8341 & $+/-0.05 \mathrm{~m}$ & $+/-0.25 \mathrm{~m}$ \\
\hline
\end{tabular}

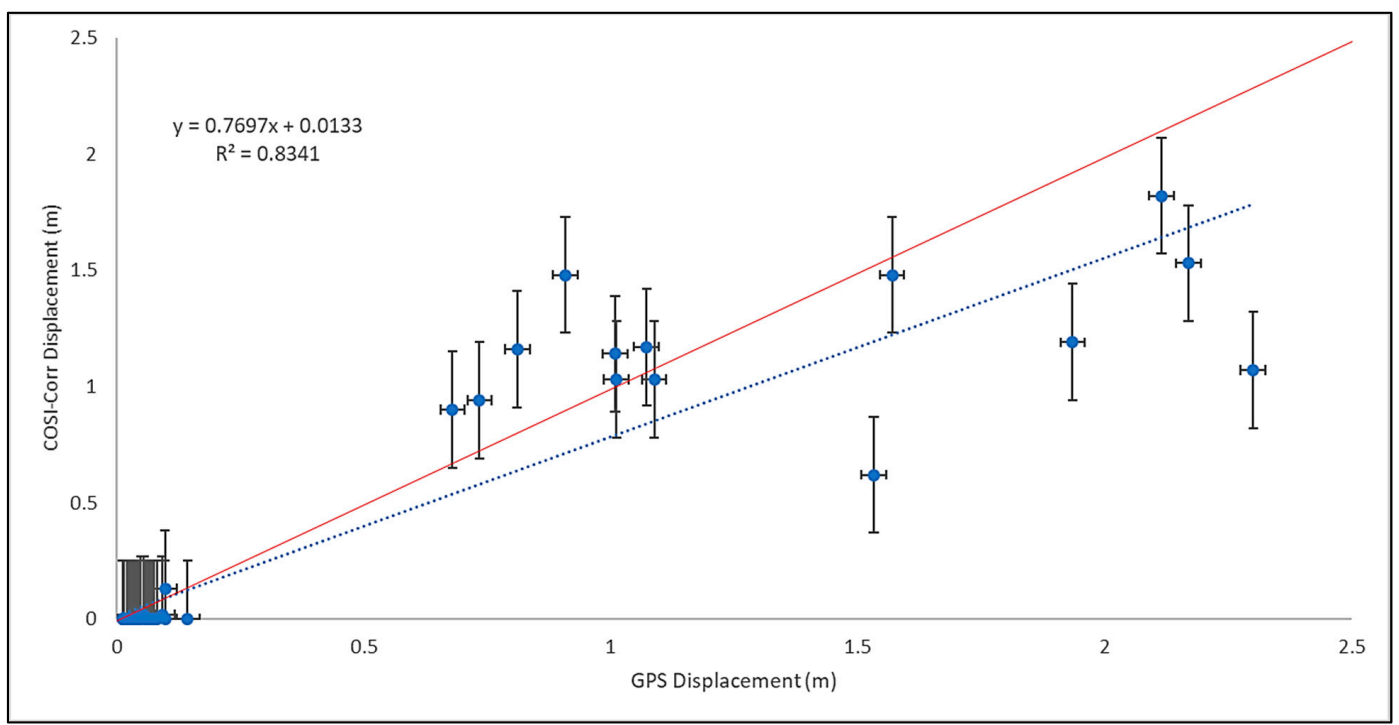

Figure 6. Graphical comparison of displacement measured by GPS (x-axis) and COSI-Corr (y-axis) from 2012 to 2016 at 55 GPS stations. Line of best fit shown as blue dashed line (see Table 4 for additional details). Line of 1:1 slope shown as red line (GPS displacement $=$ COSI-Corr displacement).

\subsection{PSI to Measure mm-Scale Deformation}

Neither GPS nor COSI-Corr can accurately measure extremely slow deformation of $<16 \mathrm{~mm} /$ year [29], so PSI is required for these measurements. Figure 7 shows PSI average velocity measurements between 19 July 2012 and 27 September 2014 across the Portuguese Bend landslide complex. PSI average velocity is measured in the line-of-sight direction $\left(26^{\circ}\right.$ from nadir, $\left.\mathrm{N} 85^{\circ} \mathrm{W}\right)$, with negative values indicating ground movement away from the satellite (which corresponds to downward and/or westward directions). There are five areas of interest that stand out when comparing PSI results with GPS and COSI-Corr: (1) AcPB Body, (2) AC and AcPB Toe, (3) KC, (4) AnPB, and VVG Scarp Reactivation, and (5) P4.

AcPB Body. As mentioned before, this is one of the more active areas within the landslide complex. A lack of PS suggest decorrelation due to rapid deformation (which occurs at a velocity $>2.5 \mathrm{~cm} /$ year). PS that border AcPB exhibit velocity around $-8 \mathrm{~mm} /$ year. PS presence within AcPB appear to act as a boundary around high landslide activity areas, which are approximated well by GPS displacement measurements (yellow, orange, and red arrows in Figure 2).

AC and AcPB Toe. This region also shows high landslide activity (Figures 2 and 3). However, presence of PS suggests there is no decorrelation due to rapid deformation and, instead, high landslide activity is localized (e.g., GPS stations are placed in areas with local instability and nearby areas may not be as unstable, hence PS presence). In fact, there are no PS along the coast (Figure 7), which is where most GPS monuments are located (see Figures 1 and 2). PS presence in this region once again act as a boundary to the high landslide activity occurring along the coast. 
KC. Houses in a residential neighborhood in Rancho Palos Verdes were built on the KC landslide, which was mapped as an active slide (Figure 1). These houses appear to be moving with KC at a velocity between -6 and $-8 \mathrm{~mm} /$ year (red PS in Figure 7). PSI velocity values follow a general trend through this neighborhood: houses undergoing greatest velocity are in the west (atop KC, red PS), toward the southeast are houses with moderate velocity (approximately $-4 \mathrm{~mm} /$ year, yellow PS), and further east are stable houses (green PS).

AnPB and VVG Scarp Reactivation. A region of red and yellow PS highlights a possible reactivation near the scarp of AnPB and VVG (Figure 7), which has been mapped as a dormant slide. Previous mapping efforts [24] have interestingly identified three small, historic soil slides (shallow, $<3 \mathrm{~m}$ deep) within AnPB and VVG (small brown areas, Figure 1). PSI results indicate the possibility of a larger, slow-moving landslide with a triangular shape that mirrors the location of the historic soil slides. The historic soil slides may be small, surficial slides caused by relatively slow movement of a larger block. PSI results give a reason to believe there may be an extremely slow reactivation near the historic scarp of the AnPB and VVG landslides.

P4. This landslide was previously mapped as a dormant slide [24] and has not been studied in any recent landslide analysis of the Palos Verdes Peninsula. P4 is home to the 400,000 $\mathrm{m}^{2} \mathrm{Three}$ Sisters Reserve, one of ten reserves that make up the Palos Verdes Nature Preserve. COSI-Corr total horizontal displacement measurements indicate the entire region surrounding P4 is undergoing significant deformation: an average velocity of $1.20 \mathrm{~m} /$ year (2011-2016) and peak velocities exceeding $4 \mathrm{~m} /$ year in early 2011 and between November 2012 and March 2014. PSI results support the general assessment of P4 instability (Figure 7): there are few PS within the P4 (except for relatively stable points in the south and west), and there is a large areal swath of relatively high-velocity PS (red and orange, between -5 and $-8 \mathrm{~mm} /$ year) in the residential neighborhood to the north.

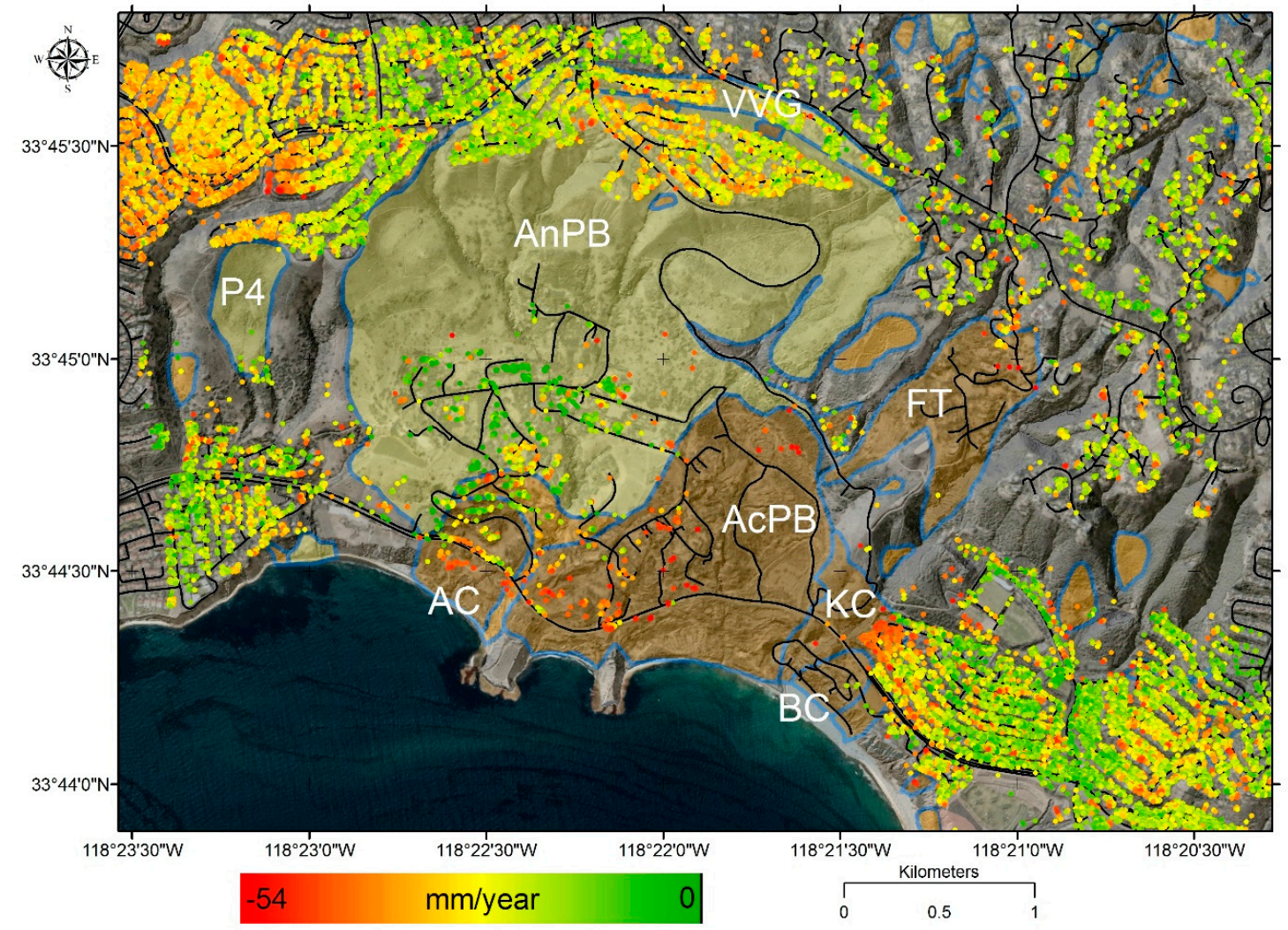

Figure 7. Average velocity (mm/year) between 19 July 2012 and 27 September 2014 measured using 40 COSMO-SkyMed images with PSI processing. Negative velocity values measure deformation away from the satellite. 


\subsection{Final Landslide Deformation Map}

A final landslide deformation map is provided in Figure 8. This map, which segments landslide activity based on Cruden and Varnes [29] landslide velocity scale, is divided as follows: slow (velocity $>1.6 \mathrm{~m} /$ year), very slow (velocity between $16 \mathrm{~mm} /$ year and $1.6 \mathrm{~m} /$ year), and extremely slow (velocity < $16 \mathrm{~mm} /$ year). Stable areas, those with no sustained deformation throughout the study period, are not labeled. Additional notes on how PSI, COSI-Corr, and GPS deformation data were converted into the final landslide deformation map are provided in Table 5.

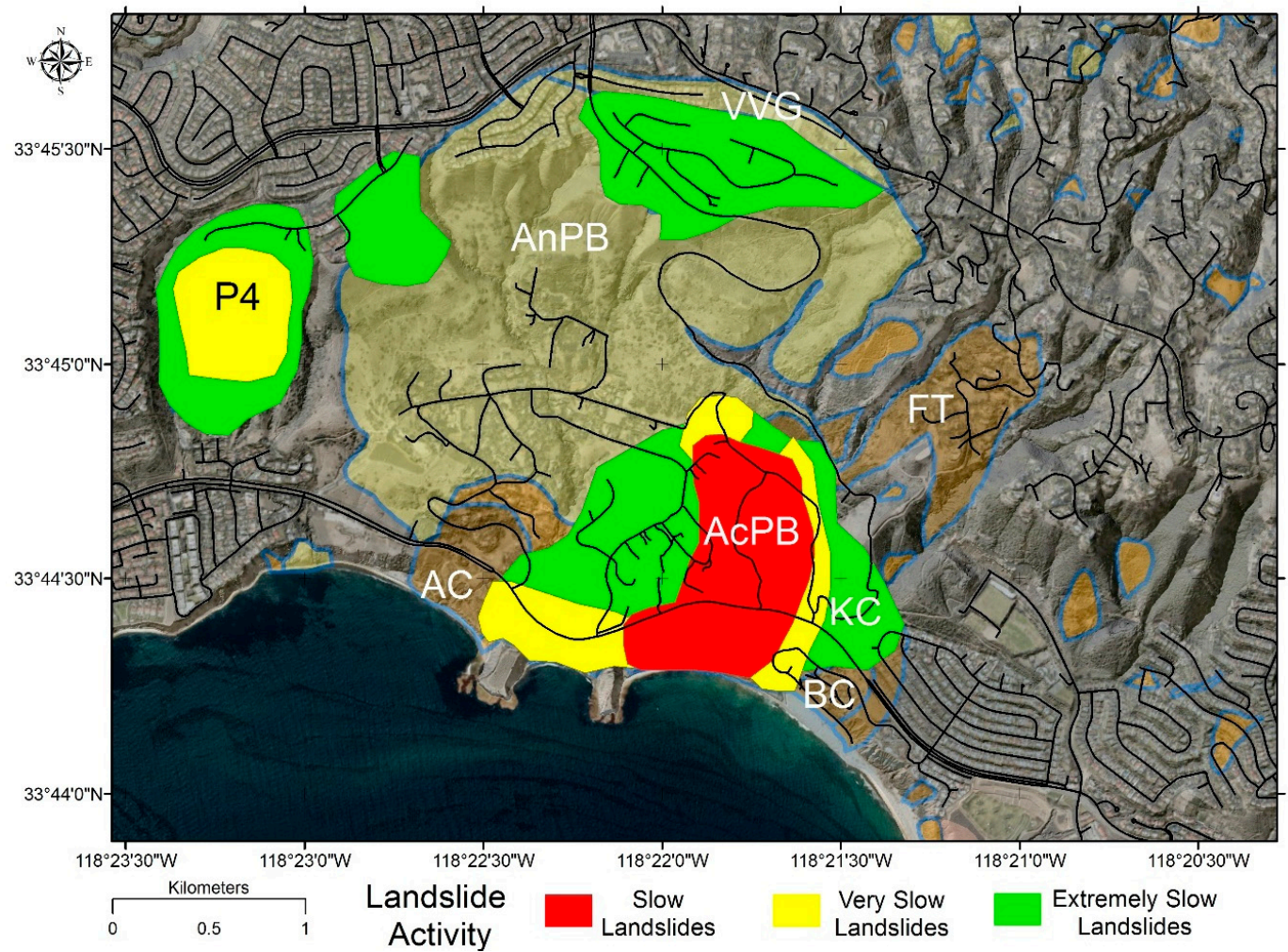

Figure 8. Activity within landslide complex based on Cruden and Varnes [29] landslide velocity scale. The slow landslide area (velocity $>1.6 \mathrm{~m} /$ year) is shown in red, the very slow landslide area (velocity between $16 \mathrm{~mm} /$ year and $1.6 \mathrm{~m} /$ year) is shown in yellow, and the extremely slow landslide area (velocity $<16 \mathrm{~mm} /$ year) is shown in green. Stable areas are those not colored with the new landslide activity red-yellow-green color scheme.

Table 5. Landslide activity descriptions based on velocity scale at the Portuguese Bend landslide complex.

\begin{tabular}{ccc}
\hline Velocity Scale & Velocity Range & Description of Landslide Activity \\
\hline Slow & $>1.6 \mathrm{~m} /$ year & $\begin{array}{c}\text { Fourteen GPS monuments experienced a velocity }>1.6 \mathrm{~m} / \text { year for a } \\
\text { portion of the study period. No location within the landslide complex } \\
\text { moved at an average velocity }>1.6 \mathrm{~m} / \text { year over the entire span of GPS } \\
\text { or COSI-Corr observations. }\end{array}$ \\
Very Slow & $16 \mathrm{~mm} /$ year-1.6 m/year & $\begin{array}{c}\text { Portions of the landslide complex that were consistently moving, as } \\
\text { measured by COSI-Corr and GPS. There was typically a lack of PS } \\
\text { presence in these areas since a velocity of } 16 \mathrm{~mm} / \text { year is near the } \\
\text { maximum PS velocity threshold of } 25 \mathrm{~mm} / \text { year. }\end{array}$ \\
\hline Extremely Slow & $<16 \mathrm{~mm} /$ year & $\begin{array}{c}\text { Velocity }<16 \mathrm{~mm} / \text { year is below the accuracy of COSI-Corr and GPS } \\
\text { measurements and, therefore, mapping of these areas relied exclusively } \\
\text { on PSI results. }\end{array}$ \\
\hline Stable & $\begin{array}{c}\text { Areas were considered stable if (1) COSI-Corr and GPS measurements } \\
\text { were below the accuracy threshold and (2) PS with a velocity of } \\
\sim 0 \text { mm/year were present. }\end{array}$ \\
\hline
\end{tabular}




\subsection{Discussion of Multi-Sensor Approaches for Landslide Monitoring}

Previous studies have utilized multi-sensor approaches to monitor landslides. In fact, many of the publications previously cited in this paper use more than one remote sensor for landslide monitoring [30-33,36,37,42,43,50-52,54,78,81,83,88,89]. Typically, multiple sensors are used to increase spatial coverage or measure deformation in three dimensions (e.g., acquisition of ascending and descending SAR images), to increase temporal coverage (e.g., combining ERS-1/-2 and ENVISAT images for almost 18 years of observation), or to optimize certain sensor parameters (e.g., X-Band SAR for high spatial resolution or L-Band SAR for vegetation penetration).

This study takes a novel approach to demonstrate the capabilities of using a multi-sensor approach (COSI-Corr and SAR along with GPS) to monitor a landslide complex undergoing deformation at three orders of magnitude: $\mathrm{mm}-, \mathrm{cm}-$, and m-scale. This type of application allows for in-depth landslide monitoring at a site with widespread displacement rates and land uses (residential, industrial, environmental, etc.) by optimizing the advantages of each technique and minimizing their limitations.

- GPS provides accurate, three-dimensional displacement measurements at a scale ranging from $\mathrm{cm}$ to $\mathrm{m}$. In remote sensing studies, GPS data are used as a source of ground-truthing and validation. GPS data are spatially limited as measurements are only available as point sources (e.g., GPS stations).

- COSI-Corr processing of optical images allows for two-dimensional displacement measurements at a scale like GPS (cm- to m-scale). COSI-Corr provides a major advantage with respect to spatial coverage, increasing the extent of displacement measurements from point sources (from GPS) to an area equal to the optical image swath. This technique is affected by noise (Figure 6) and cannot accurately measure displacements less than 1/10-pixel size of the optical images.

- PSI processing of SAR images allows for one-dimensional (line-of-sight) displacement measurements at a scale ranging from $\mathrm{mm}$ to $1-2 \mathrm{~cm}$. Although PSI cannot measure rapid deformation, it excels at measuring slow-moving deformation (e.g., landslide creep) especially over urban areas, which may be difficult to map in the field.

Monitoring landslides at various orders of magnitude can provide an asset for at-risk communities because almost all types of landslides can be detected. Continuous movement on rotational and translational slides can be annually monitored by GPS surveys or, preferably, by continuous GPS stations. These types of landslides can also be monitored through repeat acquisition of optical images from myriad of sensors on current satellites (e.g., Deimos-2, GeoEye-1, IKONOS, KOMPSAT-2, Landsat, Pleiades, RapidEye, SPOT, and WorldView-1/-2/-3). Slower moving landslides-such as the initial stages of rockfalls or topples (possibly, prior to failure), the perimeter of rotational and translational landslides, or slopes experiencing creep-may be monitored by SAR techniques, such as PSI and others. There are also many current satellites that provide coverage around the world (e.g., ALOS-2, COSMO-SkyMed, RADARSAT-2, SAOCOM-1/-2, Sentinel-1, and TerraSAR-X).

\section{Conclusions}

Continuously-moving landslides, such as the Portuguese Bend landslide complex on the Palos Verdes Peninsula in Southern California, are ideal locations for multi-sensor monitoring. The premise is that each technique (PSI, COSI-Corr, and GPS), when analyzed together, provides an advantage where the others might be limited (see Table 1). Forty COSMO-SkyMed SAR images (2012-2014) were processed using PSI to measure average velocity, eight WorldView-2 (2011-2016) optical images were processed using COSI-Corr to measure average horizontal downslope velocity, and 66 GPS monuments (2007-2017) were used to measure incremental displacement. This approach allowed for delineation of active zones within the landslide complex (during the study period between 2007 and 2017). A final landslide deformation map was produced (Figure 8), which divides the landslide complex into three activity categories based on the Cruden and Varnes [29] velocity scale: slow ( $>1.6 \mathrm{~m} /$ year), very slow (between $16 \mathrm{~mm} /$ year and $1.6 \mathrm{~m} /$ year), extremely slow ( $<16 \mathrm{~mm} /$ year), and stable. Average 
velocity measurements obtained in this study match those of previous studies [65,70] and older observations $[24,66-69,96]$. Landslides are a complex natural hazard and it may require the use of all available resources to fully detect, monitor, understand their geographic and temporal components. Hopefully one day we can use this information to confidently and accurately predict their occurrence as well.

Author Contributions: Contributions by the authors are listed using the Contributor Roles Taxonomy (CRediT). E.H.B. conceived of the project and contributed to conceptualization, formal analysis, funding acquisition, investigation, methodology, project administration, visualization, writing of the original draft, and review-editing of subsequent and final drafts. T.O. and R.E.-W. contributed to conceptualization, funding acquisition, resources, and review-editing of manuscript drafts.

Funding: This study was funded by the NASA Earth and Space Science Fellowship Program (proposal 16-EARTH16F-0086).

Acknowledgments: COSMO-SkyMed images were acquired by the Italian Space Agency and provided by the European Space Agency (ESA, proposal ID 31684). ENVISAT images were acquired and provided by ESA (proposal ID 82169). WorldView-2 images were acquired by DigitalGlobe and provided by ESA (proposal ID 36617). California landslide inventory shapefile was provided by the California Geological Survey and the California Department of Conservation. GPS survey reports were provided by the City of Rancho Palos Verdes, California. Digital elevation models were provided by the Jet Propulsion Laboratory and the United States Geological Survey. Precipitation data for Los Angeles, California were provided by the National Oceanic and Atmospheric Administration.

Conflicts of Interest: The authors declare no conflict of interest.

\section{Abbreviations}

$\begin{array}{ll}\text { AC } & \text { Abalone Cove (Landslide) } \\ \text { AcPB } & \text { Active Portuguese Bend (Landslide) } \\ \text { AnPB } & \text { Ancient Portuguese Bend (Landslide) } \\ \text { ASI } & \text { Italian Space Agency } \\ \text { BC } & \text { Beach Club (Landslide) } \\ \text { COSI-Corr } & \text { Co-registration of Optically Sensed Images and Correlation } \\ \text { ESA } & \text { European Space Agency } \\ \text { FT } & \text { Flying Triangle (Landslide) } \\ \text { GNSS } & \text { Global Navigation Satellite System } \\ \text { GPS } & \text { Global Positioning System } \\ \text { KC } & \text { Klondike Canyon (Landslide) } \\ \text { P4 } & \text { Parcel 4 (Landslide) } \\ \text { PS } & \text { Persistent Scatterers } \\ \text { PSI } & \text { Persistent Scatterer Interferometry } \\ \text { SAR } & \text { Synthetic Aperture Radar } \\ \text { VVG } & \text { Valley View Graben (Landslide) }\end{array}$

\section{References}

1. Hungr, O. Dynamics of rapid landslides. In Progress of Landslide Science; Fukuoka, H., Ed.; Springer: Berlin/Heidelberg, Germany, 2007; pp. 47-57.

2. Dai, F.C.; Lee, C.F.; Ngai, Y.Y. Landslide risk assessment and management: An overview. Eng. Geol. 2002, 64, 65-87. [CrossRef]

3. Petley, D. Global patterns of loss of life from landslides. Geology 2012, 40, 927-930. [CrossRef]

4. Ge, Y.G.; Lindell, M.K. County planners' perceptions of land-use planning tools for environmental hazard mitigation: A survey in the US Pacific states. Environ. Plan. B 2006, 43, 716-736. [CrossRef]

5. Scolobig, A.; Thompson, M.; Linnerooth-Bayer, J. Compromise not consensus: Designing a participatory process for landslide risk mitigation. Nat. Hazards 2016, 81, 45-68. [CrossRef]

6. Dou, J.; Yamagishi, H.; Pourghasemi, H.R.; Yunus, A.P.; Song, X.; Xu, Y.; Zhu, Z. An integrated artificial neural network model for the landslide susceptibility assessment of Osado Island, Japan. Nat. Hazards 2015, 78, 1749-1776. [CrossRef] 
7. Gullà, G.; Antronico, L.; Iaquinta, P.; Terranova, O. Susceptibility and triggering scenarios at a regional scale for shallow landslides. Geomorphology 2008, 99, 39-58. [CrossRef]

8. Hervás, J.; Barredo, J.I.; Rosin, P.L.; Pasuto, A.; Mantovani, F.; Silvano, S. Monitoring landslides from optical remotely sensed imagery: The case history of Tessina landslide, Italy. Geomorphology 2003, 54, 63-75. [CrossRef]

9. Intrieri, E.; Di Traglia, F.; Del Ventisette, C.; Gigli, G.; Mugnai, F.; Luzi, G.; Casagli, N. Flank instability of Stromboli volcano (Aeolian Islands, Southern Italy): Integration of GB-InSAR and geomorphological observations. Geomorphology 2013, 201, 60-69. [CrossRef]

10. Intrieri, E.; Gigli, G.; Mugnai, F.; Fanti, R.; Casagli, N. Design and implementation of a landslide early warning system. Eng. Geol. 2012, 147-148, 124-136. [CrossRef]

11. Jaboyedoff, M.; Oppikofer, T.; Abellán, A.; Derron, M.-H.; Loye, A.; Metzger, R.; Pedrazzini, A. Use of LIDAR in landslide investigations: A review. Nat. Hazards 2012, 61, 5-28. [CrossRef]

12. Lu, P.; Casagli, N.; Catani, F.; Tofani, V. Persistent Scatterers Interferometry Hotspot and Cluster Analysis (PSI-HCA) for detection of extremely slow-moving landslides. Int. J. Remote Sens. 2012, 33, 466-489. [CrossRef]

13. McKean, J.; Roering, J. Objective landslide detection and surface morphology mapping using high-resolution airborne laser altimetry. Geomorphology 2004, 57, 331-351. [CrossRef]

14. Metternicht, G.; Hurni, L.; Gogu, R. Remote sensing of landslides: An analysis of the potential contribution to geo-spatial systems for hazard assessment in mountainous environments. Remote Sens. Environ. 2005, 98, 284-303. [CrossRef]

15. Michoud, C.; Carrea, D.; Costa, S.; Derron, M.-H.; Jaboyedoff, M.; Delcourt, C.; Maquaire, O.; Letortu, P.; Davidson, R. Landslide detection and monitoring capability of boat-based mobile laser scanning along Dieppe coastal cliffs, Normandy. Landslides 2015, 12, 403-418. [CrossRef]

16. Ramesh, M.V. Design, development, and deployment of a wireless sensor network for detection of landslides. Ad Hoc Netw. 2014, 13, 2-18. [CrossRef]

17. Schaefer, L.N.; Lu, Z.; Oommen, T. Dramatic volcanic instability revealed by InSAR. Geology 2015, 43, 743-746. [CrossRef]

18. Tarantino, C.; Blonda, P.; Pasquariello, G. Remote sensed data for automatic detection of land-use changes due to human activity in support to landslide studies. Nat. Hazards 2007, 41, 245-267. [CrossRef]

19. Tarolli, P.; Sofia, G.; Dalla Fontana, G. Geomorphic features extraction from high-resolution topography: Landslide crowns and bank erosion. Nat. Hazards 2012, 61, 65-83. [CrossRef]

20. Thai Pham, B.; Prakash, I.; Dou, J.; Singh, S.K.; Trong Trinh, P.; Trung Tran, H.; Minh Le, T.; Phong Tran, V.; Kim Khoi, D.; Shirzadi, A.; et al. A novel hybrid approach for landslide susceptibility modeling using rotation forest ensemble and different base classifiers. Geocartography Int. 2018, 1-38. [CrossRef]

21. Young, A.P.; Ashford, S.A. Instability investigation of cantilevered seacliffs. Earth Surf. Process. Landf. 2008, 33, 1661-1677. [CrossRef]

22. Youssef, A.M.; Maerz, N.H.; Hassan, A.M. Remote sensing applications to geological problems in Egypt: Case study, slope instability investigation, Sharm El-Sheikh/Ras-Nasrani Area, Southern Sinai. Landslides 2009, 6, 353. [CrossRef]

23. Zhao, C.; Lu, Z.; Zhang, Q.; de la Fuente, J. Large-area landslide detection and monitoring with ALOS/PALSAR imagery data over Northern California and Southern Oregon, USA. Remote Sens. Environ. 2012, 124, 348-359. [CrossRef]

24. Haydon, W.D. Landslide Inventory Map of the Palos Verdes Peninsula, Los Angeles County; Geologic Information and Publications; California Geological Survey: Sacramento, CA, USA, 2007.

25. McMillan, J.R.; Haydon, W.D. Earthquake-Induced Landslide Zones in the Torrance 7.5-Minute Quadrangle, Los Angeles County, California; California Geological Survey Seismic Hazard Zone Report 035, Section 2; California Department of Conservation: Sacramento, CA, USA, 1998; pp. 19-38.

26. McMillan, J.R.; Haydon, W.D. Earthquake-Induced Landslides Zones in the San Pedro 7.5-Minute Quadrangle, Los Angeles County, California; California Geological Survey Open File Report 98-24, Section 2; California Department of Conservation: Sacramento, CA, USA, 1998; pp. 15-30.

27. McMillan, J.R.; Haydon, W.D. Earthquake-Induced Landslide Zones in the Redondo Beach 7.5-Minute Quadrangle, Los Angeles County; California Geological Survey Seismic Hazard Zone Report 031, Section 2; California Department of Conservation: Sacramento, CA, USA, 1998; pp. 17-35. 
28. McGee, M. Survey Report of the Portuguese Bend Landslide Monitoring Surveys for the City of Rancho Palos Verdes; McGee Surveying Consulting: Santa Barbara, CA, USA, 2017; 234p.

29. Cruden, D.M.; Varnes, D.L. Chapter 3: Landslide types and processes. In Landslides: Investigation and Mitigation, Special Report 247; Turner, A.K., Schuster, R.J., Eds.; Transportation Research Board, National Research Council: Washington, DC, USA, 1996; pp. 36-75.

30. Behling, R.; Roessner, S.; Segl, K.; Kleinschmit, B.; Kaufmann, H. Robust automated image co-registration of optical multi-sensor time series data: Database generation for multi-temporal landslide detection. Remote Sens. 2014, 6, 2572-2600. [CrossRef]

31. Casagli, N.; Cigna, F.; Bianchini, S.; Hölbling, D.; Füreder, P.; Righini, G.; Del Conte, S.; Friedl, B.; Schneiderbauer, S.; Iasio, C.; et al. Landslide mapping and monitoring by using radar and optical remote sensing: Examples from the EC-FP7 project SAFER. Remote Sens. Soc. Environ. 2016, 4, 92-108. [CrossRef]

32. Joyce, K.E.; Samsonov, S.V.; Levick, S.R.; Engelbrecht, J.; Belliss, S. Mapping and monitoring geological hazards using optical, LiDAR, and synthetic aperture RADAR image data. Nat. Hazards 2014, 73, 137-163. [CrossRef]

33. Youssef, A.M.; Sefry, S.A.; Pradhan, B.; Abu Alfadail, E. Analysis on causes of flash flood in Jeddah city (Kingdom of Saudi Arabia) of 2009 and 2011 using multi-sensor remote sensing data and GIS. Geomat. Nat. Hazards Risk 2016, 7, 1018-1042. [CrossRef]

34. Akbarimehr, M.; Motagh, M.; Haghshenas-Haghighi, M. Slope stability assessment of the Sarcheshmeh landslide, northeast Iran, investigated using InSAR and GPS observations. Remote Sens. 2013, 5, 3681-3700. [CrossRef]

35. Ao, M.; Wang, C.; Xie, R.; Zhang, X.; Hu, J.; Du, Y.; Li, Z.; Zhu, J.; Dai, W.; Kuang, C. Monitoring the land subsidence with persistent scatterer interferometry in Nansha District, Guangdong, China. Nat. Hazards 2015, 75, 2947-2964. [CrossRef]

36. Bouali, E.H.; Oommen, T.; Escobar-Wolf, R. Mapping of slow landslides on the Palos Verdes Peninsula using the California landslide inventory and persistent scatterer interferometry. Landslides 2018, 15, 439-452. [CrossRef]

37. Bovenga, F.; Nitti, D.O.; Fornaro, G.; Radicioni, F.; Stoppini, A.; Brigante, R. Using C/X-band SAR interferometry and GNSS measurements for the Assisi landslide analysis. Int. J. Remote Sens. 2013, 34, 4083-4104. [CrossRef]

38. Chen, F.; Lin, H.; Yeung, K.; Cheng, S. Detection of slope instability in Hong Kong based on multi-baseline Differential SAR Interferometry using ALOS PALSAR data. GISci. Remote Sens. 2010, 47, 208-220. [CrossRef]

39. Crosetto, M.; Gili, J.A.; Monserrat, O.; Cuevas-González, M.; Corominas, J.; Serral, D. Interferometric SAR monitoring of the Vallcebre landslide (Spain) using corner reflectors. Nat. Hazards Earth Syst. Sci. 2013, 13, 923-933. [CrossRef]

40. Gullà, G.; Peduto, D.; Borrelli, L.; Antronico, L.; Fornaro, G. Geometric and kinematic characterization of landslides affecting urban areas: The Lungro case study (Calabria, Southern Italy). Landslides 2017, 14, 171-188. [CrossRef]

41. Herrera, G.; Gutiérrez, F.; García-Davalillo, J.C.; Guerrero, J.; Notti, D.; Galve, J.P.; Fernández-Merodo, J.A.; Cooksley, G. Multi-sensor advanced DInSAR monitoring of very slow landslides: The Tena Valley case study (Central Spanish Pyrenees). Remote Sens. Environ. 2013, 128, 31-43. [CrossRef]

42. Komac, M.; Holley, R.; Mahapatra, P.; van der Marel, H.; Bavec, M. Coupling of GPS/GNSS and radar interferometric data for a 3D surface displacement monitoring of landslides. Landslides 2015, 12, 241-257. [CrossRef]

43. Strozzi, T.; Ambrosi, C.; Raetzo, H. Interpretation of aerial photographs and satellite SAR interferometry for the inventory of landslides. Remote Sens. 2013, 5, 2554-2570. [CrossRef]

44. Xiao, R.; He, X. GPS and InSAR time series analysis: Deformation monitoring application in a hydraulic engineering resettlement zone, southwest China. Math. Prob. Eng. 2013, 11. [CrossRef]

45. Fernandez, P.; Whitworth, M. A new technique for the detection of large scale landslides in glacio-lacustrine deposits using image correlation based upon aerial imagery: A case study from the French Alps. Int. J. Appl. Earth Obs. Geoinform. 2016, 52,1-11. [CrossRef]

46. Le Bivic, R.; Allemand, P.; Quiquerez, A.; Delacourt, C. Potential and limitation of SPOT-5 ortho-image correlation to investigate the cinematics of landslides: The example of "Mare à Poule d'Eau" (Réunion, France). Remote Sens. 2017, 9, 106. [CrossRef] 
47. Turner, D.; Lucieer, A.; de Jong, S.M. Time series analysis of landslide dynamics using an unmanned aerial vehicle (UAV). Remote Sens. 2015, 7, 1736-1757. [CrossRef]

48. Bianchini, S.; Cigna, F.; Del Ventisette, C.; Moretti, S.; Casagli, N. Monitoring landslide-induced displacements with TerraSAR-X Persistent Scatterer Interferometry (PSI): Gimigliano case study in Calabria Region (Italy). Int. J. Geosci. 2013, 4, 1467-1482. [CrossRef]

49. Bianchini, S.; Cigna, F.; Righini, G.; Proietti, C.; Casagli, N. Landslide HotSpot Mapping by means of Persistent Scatterer Interferometry. Environ. Earth Sci. 2012, 67, 1155-1172. [CrossRef]

50. Del Ventisette, C.; Righini, G.; Moretti, S.; Casagli, N. Multitemporal landslides inventory map updating using spaceborne SAR analysis. Int. J. Appl. Earth Obs. Geoinform. 2014, 30, 238-246. [CrossRef]

51. Hölbling, D.; Füreder, P.; Antolini, F.; Cigna, F.; Casagli, N.; Lang, S. A semi-automated object-based approach for landslide detection validated by Persistent Scatterer Interferometry measures and landslide inventories. Remote Sens. 2012, 4, 1310-1336. [CrossRef]

52. Piacentini, D.; Devoto, S.; Mantovani, M.; Pasuto, A.; Prampolini, M.; Soldati, M. Landslide susceptibility modeling assisted by Persistent Scatterer Interferometry (PSI): An example from the northwestern coast of Malta. Nat. Hazards 2015, 78, 681-697. [CrossRef]

53. Tofani, V.; Raspini, F.; Catani, F.; Casagli, N. Persistent Scatterer Interferometry (PSI) technique for landslide characterization and monitoring. Remote Sens. 2013, 5, 1045-1065. [CrossRef]

54. Delacourt, C.; Allemand, P.; Casson, B.; Vadon, H. Velocity field of the "La Clapière" landslide measured by the correlation of aerial and QuickBird satellite images. Geophys. Res. Lett. 2004, 31, L15619. [CrossRef]

55. Laribi, A.; Walstra, J.; Ougrine, M.; Seridi, A.; Dechemi, N. Use of digital photogrammetry for the study of unstable slopes in urban areas: Case study of the El Biar landslide, Algiers. Eng. Geol. 2015, 187, 73-83. [CrossRef]

56. Tung, S.-H.; Weng, M.-C.; Shih, M.-H. Measuring the in situ deformation of retaining walls by the digital image correlation method. Eng. Geol. 2013, 166, 116-126. [CrossRef]

57. Ferretti, A.; Prati, C.; Rocca, F. Nonlinear subsidence rate estimation using permanent scatterers in differential SAR interferometry. IEEE Trans. Geosci. Remote 2000, 38, 2202-2212. [CrossRef]

58. Ferretti, A.; Prati, C.; Rocca, F. Permanent scatterers in SAR interferometry. IEEE Trans. Geosci. Remote 2001, 39, 8-20. [CrossRef]

59. Crosetto, M.; Monserrat, O.; Cuevas-González, M.; Devanthéry, N.; Crippa, B. Persistent Scatterer Interferometry: A review. ISPRS J. Photogramm. Remote Sens. 2016, 115, 78-89. [CrossRef]

60. Varnes, D.J. Slope movement types and processes. In Landslides: Analysis and Control., Special Report 176; Schuster, R.L., Krizek, R.J., Eds.; Transportation Research Board, National Research Council: Washington, DC, USA, 1978; pp. 11-33.

61. Wieczorek, G.F. Preparing a detailed landslide-inventory map for hazard evaluation and reduction. B Assoc. Eng. Geol. 1984, 21, 337-342. [CrossRef]

62. Keaton, J.R.; DeGraff, J.V. Chapter 9: Surface observation and geologic mapping. In Landslides: Investigation and Mitigation, Special Report 247; Turner, A.K., Schuster, R.J., Eds.; Transportation Research Board, National Research Council: Washington, DC, USA, 1996; pp. 178-230.

63. Merriam, R. Portuguese Bend landslide, Palos Verdes Hills, California. J. Geol. 1960, 68, 140-153. [CrossRef]

64. Woodring, W.P.; Bramlette, M.N.; Kew, W.S.W. Geology and Paleontology of Palos Verdes Hills; U.S. Geological Survey, Professional Paper 207; United States Department of the Interior: Washington, DC, USA, 1946; 145p.

65. Calabro, M.D.; Schmidt, D.A.; Roering, J.J. An examination of seasonal deformation at the Portuguese Bend landslide, Southern California, using radar interferometry. J. Geophys. Res. 2010, 115, 10. [CrossRef]

66. Ehlig, P.L.; Bean, R.T. Dewatering of the Abalone Cove landslide, Rancho Palos Verdes, Los Angeles County, CA. In Volume and Guidebook: Landslides and Landslide Abatement, Geological Society of America, Palos Verdes Peninsula, Southern California; Cooper, J.D., Ed.; Geological Society of America Cordilleran Section: Anaheim, CA, USA, 1982; pp. 67-79.

67. Kayen, R.E.; Lee, H.J.; Hein, J.R. Influence of the Portuguese Bend landslide on the character of the effluent-affected sediment deposit, Palos Verdes margin, Southern California. Cont. Shelf Res. 2002, 22, 911-922. [CrossRef]

68. Ehlig, P.L. Evolution, mechanics and mitigation of the Portuguese Bend landslide, Palos Verdes Peninsula, CA. In Engineering Geology Practice in Southern California; Pipkin, B.W., Proctor, R.J., Eds.; Special Publication No. 4; Associations of Engineering Geology: Redwood City, CA, USA, 1992. 
69. Proffer, K.A. Ground water in the Abalone Cove landslide, Palos Verdes Peninsula, southern California. In Landslides/Landslide Mitigation; Slosson, J.E., Keene, A.G., Johnson, J.A., Eds.; Geological Society of America: Boulder, CO, USA, 1992; pp. 69-82.

70. City of Rancho Palos Verdes. Landslide Workshop. 2012. Available online: http://www.rpvca.gov/ documentcenter/view/5564 (accessed on 7 March 2019).

71. Osier, V. Rancho Palos Verdes Mulling Long-Term Fix for Portuguese Bend Landslide. Daily Breeze, 27 January 2018. Available online: https://www.dailybreeze.com/2018/01/27/rancho-palos-verdes-mulling-longterm-fix-for-portuguese-bend-landslide/ (accessed on 1 March 2019).

72. Los Angeles Regional Imagery Acquisition Consortium (LAR-IAC). 10-foot Digital Elevation Model (DEM)-LAR-IAC-Public Domain. 2006. Available online: https://egis3.lacounty.gov/dataportal/2011/ 01/26/2006-10-foot-digital-elevation-model-dem-public-domain/ (accessed on 1 March 2019).

73. Leprince, S.; Ayoub, F.; Lin, J.; Avouac, J.-P.; Muse, P.; Barbot, S. COSI-Corr: Measuring Ground Deformation Using Optical Satellite and Aerial Images. 2004. Available online: http://www.tectonics.caltech.edu/slip_ history/spot_coseis/index.html (accessed on 1 March 2019).

74. Leprince, S.; Barbot, S.; Ayoub, F.; Avouac, J.-P. Automatic, precise, ortho-rectification and co-registration for satellite image correlation: Application to seismotectonics. IEEE Trans. Geosci. Remote 2007, 45, 1529-1558. [CrossRef]

75. Ayoub, F.; Leprince, S.; Avouac, J. User's Guide to COSI-CORR: Co-Registration of Optically Sensed Images and Correlation. California Institute of Technology, 2017. Available online: http://www.tectonics.caltech.edu/ slip_history/spot_coseis/pdf_files/CosiCorr-Guide2017.pdf (accessed on 30 March 2019).

76. Bridges, N.T.; Ayoub, F.; Avouac, J.-P.; Leprince, S.; Lucas, A.; Mattson, S. Earth-like sand fluxes on Mars. Nature 2012, 485, 339-342. [CrossRef]

77. Lucieer, A.; de Jong, S.M.; Turner, D. Mapping landslide displacements using Structure from Motion (SfM) and image correlation of multi-temporal UAV photography. Prog. Phys. Geog. 2014, 38, 97-116. [CrossRef]

78. Necsoiu, M.; Leprince, S.; Hooper, D.M.; Dinwiddie, C.L.; McGinnis, R.N.; Walter, G.R. Monitoring migration rates of an active subarctic dune field using optical imagery. Remote Sens. Environ. 2009, 113, 2441-2447. [CrossRef]

79. Vermeesch, P.; Drake, N. Remotely sensed dune celerity and sand flux measurements of the world's fastest barchans (Bodélé, Chad). Geophys. Res. Lett. 2008, 35, L24404. [CrossRef]

80. Leprince, S. COSI-Corr-Brief Description of COSI-Corr-Introduction; The COSI-Corr Project Discussion Group. 2008. Available online: http://tecto.gps.caltech.edu/forum/viewtopic.php?id=2 (accessed on 30 March 2019).

81. Bayer, B.; Simoni, A.; Schmidt, D.; Bertello, L. Using advanced InSAR techniques to monitor landslide deformations induced by tunneling in the Northern Apennines, Italy. Eng. Geol. 2017, 226, 20-32. [CrossRef]

82. Béjar-Pizarro, M.; Notti, D.; Mateos, R.M.; Ezquerro, P.; Centolanza, G.; Herrera, G.; Bru, G.; Sanabria, M.; Solari, L.; Duro, J.; et al. Mapping vulnerable urban areas affected by slow-moving landslides using Sentinel-1 InSAR data. Remote Sens. 2017, 9, 876. [CrossRef]

83. Bianchini, S.; Ciampalini, A.; Raspini, F.; Bardi, F.; Di Traglia, F.; Moretti, S.; Casagli, N. Multi-temporal evaluation of landslide movements and impacts on buildings in San Fratello (Italy) by means of C-band and X-band PSI data. Pure Appl. Geophys. 2015, 172, 3043-3065. [CrossRef]

84. Bianchini, S.; Solari, L.; Casagli, N. A GIS-based procedure for landslide intensity evaluation and specific risk analysis supported by Persistent Scatterers Interferometry (PSI). Remote Sens. 2017, 9, 1093. [CrossRef]

85. Carlà, T.; Raspini, F.; Intrieri, E.; Casagli, N. A simple method to help determine landslide susceptibility from spaceborne InSAR data: The Montescaglioso case study. Environ. Earth Sci. 2016, 75, 1492. [CrossRef]

86. Ciampalini, A.; Raspini, F.; Lagomarsino, D.; Catani, F.; Casagli, N. Landslide susceptibility map refinement using PSInSAR data. Remote Sens. Environ. 2016, 184, 302-315. [CrossRef]

87. Oliveira, S.C.; Zêzere, J.L.; Catalão, J.; Nico, G. The contribution of PSInSAR interferometry to landslide hazard in weak rock-dominated areas. Landslides 2015, 12, 703-719. [CrossRef]

88. Rosi, A.; Tofani, V.; Tanteri, L.; Tacconi Stefanelli, C.; Agostini, A.; Catani, F.; Casagli, N. The new landslide inventory of Tuscany (Italy) updated with PS-InSAR: Geomorphological features and landslide distribution. Landslides 2018, 15, 5-19. [CrossRef]

89. Sara, F.; Silvia, B.; Sandro, M. Landslide inventory updating by means of Persistent Scatterer Interferometry (PSI): The Setta basin (Italy) case study. Geomat. Nat. Hazards Risk 2015, 6, 419-438. [CrossRef] 
90. Sun, Q.; Zhang, L.; Ding, X.L.; Hu, J.; Li, Z.W.; Zhu, J.J. Slope deformation prior to Zhouqu, China landslide from InSAR time series analysis. Remote Sens. Environ. 2015, 156, 45-57. [CrossRef]

91. Xue, Y.T.; Meng, X.M.; Li, K.; Chen, G. Loess Slope Instability Assessment Based on PS-InSAR Detected and Spatial Analysis in Lanzhou Region, China. Adv. Mat. Res. 2015, 1065-1069, 2342-2352. [CrossRef]

92. Italian Space Agency. COSMO-SkyMed SAR Products Handbook, Rev. 2; Italian Space Agency: Rome, Italy, 2009; $105 p$.

93. Sarmap. SARscape v. 5.2 Software; Sarmap: Caslano, Switzerland, 2017.

94. Schlögel, R.; Doubre, C.; Malet, J.-P.; Masson, F. Landslide deformation monitoring with ALOS/PALSAR imagery: A D-InSAR geomorphological interpretation method. Geomorphology 2015, 231, 314-330. [CrossRef]

95. National Oceanic and Atmospheric Administration (NOAA). Climate at a Glance. 2018. Available online: https://www.ncdc.noaa.gov/cag/city/time-series/USW00023174/pcp/all/6/2007-2018?base_prd=true\& firstbaseyear=1944\&lastbaseyear=2000 (accessed on 1 March 2019).

96. Ehlig, P.L. The Palos Verdes Peninsula: Its physiography, land use and geologic setting. In Volume and Guidebook: Landslides and Landslide Abatement, Geological Society of America, Palos Verdes Peninsula, Southern California; Cooper, J.D., Ed.; Geological Society of America Cordilleran Section: Anaheim, CA, USA, 1982; pp. 3-6.

(C) 2019 by the authors. Licensee MDPI, Basel, Switzerland. This article is an open access article distributed under the terms and conditions of the Creative Commons Attribution (CC BY) license (http://creativecommons.org/licenses/by/4.0/). 